\title{
Essential Competence as a Determiner of Learning Media Development in Network-Based on 3D Augmented Reality in the Pre-Teacher Civil Engineering Education Study Program
}

\author{
https://doi.org/10.3991/ijim.v16i05.28999 \\ Machmud Sugandi $\left.{ }^{(}\right)$, Juharyanto, Made Wena, Sutrisno \\ Universitas Negeri Malang, Malang, Indonesia \\ r.machmud.ft@um.ac.id
}

\begin{abstract}
The purpose of this study was to determine and apply (1) the Augmented Reality (AR) development process; (2) AR model design; (3) application of AR technology; and (4) the results of AR development that can be used as a support for learning methods in the Building Engineering Education Study Program for the implementation of the 2020 curriculum. Adequate teaching materials are needed so that prospective professional teachers can quickly learn learning materials using the latest learning facilities and meet the demands of 21 st-century learning. The main material that must be mastered by prospective professional teachers of the Construction and Housing Engineering Expertise Program include statics, building construction, construction drawings, and construction management. The number of materials contained in each main material requires mapping of essential competencies that must be mastered by prospective professional teacher students as the basic material for learning the Construction and Housing Engineering Expertise Program. The essential competencies that have been identified are used as materials for developing 3D AR-based learning media that can be delivered online so that they can be accessed by students without being limited by the dimensions of space and time. The results of the development of learning media will make it easier for prospective professional teacher students to learn the main content.
\end{abstract}

Keywords - essential competencies, pre-teacher, construction, housing engineering expertise program

\section{Introduction}

The development of science and technology in the business and industrial sectors, at work, and economic growth also has an impact on the implementation of vocational education to prepare workers to meet the recent competencies. The paradigm of implementing vocational education that adheres to demand is a driver of economic growth. Therefore, vocational education graduates are always updated to respond to the existing 
competencies in the market. Vocational education drives economic growth which in its development is aligned with industry needs [1], [2].

The fulfillment of competencies by the needs of the business world and industry carried out by educational institutions at the vocational level is largely determined by human resources and the adequacy of infrastructure that support the formation of graduate competencies. Teacher and industrial instructors involved in learning activities in schools and industry are the critical factors of the formation of these competencies. Vocational schoolteachers have their characteristics in learning that they always have an orientation to prepare their students to work in an industry sector [3]. Besides this, teachers' vocational education is also required to facility competent graduates following the 21 st-century demands [4].

Vocational teachers as elements of human resources in the construction and property technology expertise program are required to have professional abilities to convey knowledge and skills in the expertise competencies of sanitation and maintenance building construction, road construction, irrigation and bridges, construction, and property business, and design building information and modeling [5]. To be professional in the four competencies in the pre-teacher education period, of course, requires hard work for lecturers and students. Related to this more, the pre-teacher vocational education training framework has four dimensions that match the various skills teachers need to adapt their methods to a changing environment including digital culture, globalization, and the emergence of a knowledge-based society [6], [7].

The use of information and communication technology in learning is growing rapidly Vocational High School teachers can take advantage of various forms of technology to support teaching in the field of construction that also leads to digitization, such as animation, simulation, Augmented Reality [8]-[10] and [11] as well as online learning platforms. For technology to be used effectively in learning, teachers need to have a good understanding of how to link learning technology with subject content and the learning strategies applied [11]-[13].

The problems raised by professional teachers of the Construction and Property Technology Expertise Program in learning at Vocational High School include: (1) the lack of availability of professional teachers by the expertise program; (2) there is a change in the orientation of student learning outcomes in the operational curriculum at the education unit level that has not been widely disseminated in SMK; (3) the lack of creativity and innovation of teachers using IT in learning in the 21 st-century, (4) there is a change in the learning achievement of each vocational subject that has not been accompanied by training for teachers, and (5) there is no restructuring of learning facilities following demands for learning outcomes and the existence of disruptive learning in the current era. As a solution to these problems, teaching materials are developed that are responsive to the demands of 21 st-century teachers using AR technology in Pre-Teacher education in the field of Civil Engineering [11], [13].

The purpose of the research to be carried out is to find out and apply (1) the Augmented Reality (AR) development process; (2) AR model design; (3) application of AR technology; and (4) the results of AR development that can be used as a support for learning methods in pre-teacher education in civil engineering education. The importance of research and development of AR 3D-based teaching materials for prospective students of civil engineering education professional teachers is to make it 
easier for students to understand concepts and skills in a real form that is visualized in 3D images so that learning outcomes are achieved well.

\section{Method}

The method used in this study is classified as Research and Development ( $\mathrm{R} \&$ D) by adopting the ADDIE method whose stages include: (1) Analysis, (2) Design, (3) Development, (4) Implementation, and (5) Evaluation [14]. The adoption and modification of the development method are carried out at the analysis stage which includes an analysis of the essential competencies of learning materials in the field of civil engineering and an analysis of the needs for developing learning media by the demands of learning in the XXI century. The method of developing teaching materials at the analysis stage is a key stage in developing this learning media. The results of the initial stage are designed, developed, implemented, and evaluated to obtain learning media that are by the learning needs of pre-teacher education in the future. The stages of development are presented in Figure 1 below.

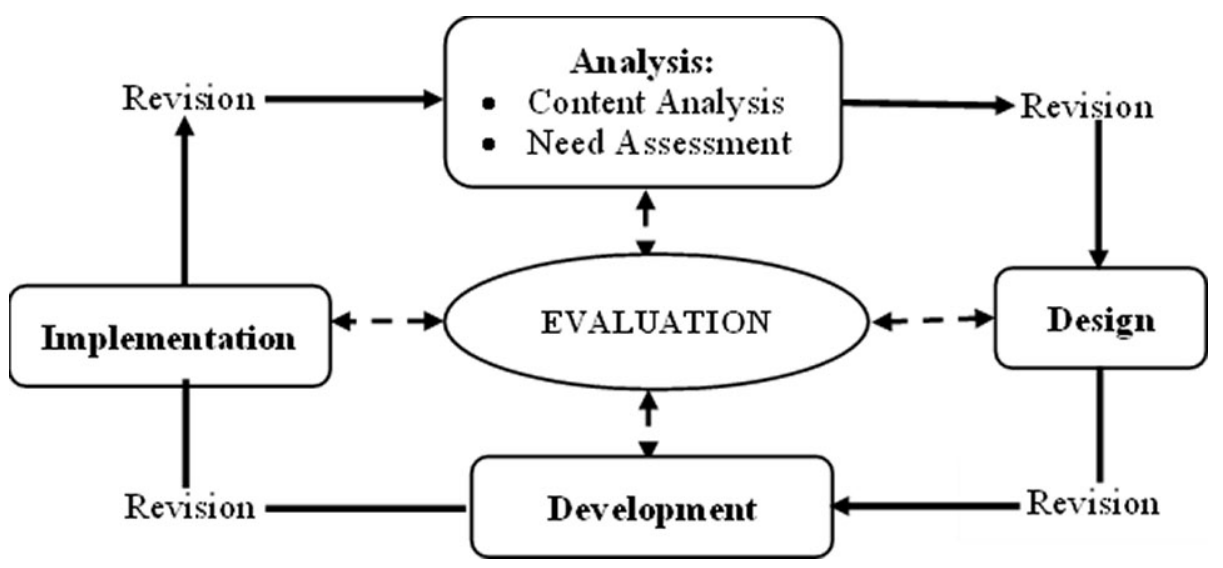

Fig. 1. Modification of ADDIE model development

Development of learning media content for pre-teacher civil engineering education based on essential competencies that have been formulated in one theme and integrated into 21 st-century teaching and learning with the following stages: 1) focusing on 21st-century skills, content knowledge, and expertise; 2) Building understanding across and between core courses and interdisciplinary themes; 3) Emphasizing the understanding of in-depth knowledge material; 4) Engage students with relevant data, tools, and real-world work into on-campus learning; and 5) It is possible to conduct an assessment of learning completeness with several measures [15], [16].

Learning content that has been packaged in one theme is an integration of several study materials from the description of essential competencies used as the basis for developing 3D Augmented Reality-based learning media. The development of digital learning media in pre-teacher education aims to produce prospective teacher graduates who can utilize the latest information technology in carrying out teaching tasks in the 
future [17]-[19]. Digitization in learning in civil engineering vocational schools is part of the innovation and creativity of each teacher. Augmented Reality (AR) is a technology that combines visual images with the real world, where visual images will be displayed with the help of certain devices [20].

\section{Results and discussion}

\subsection{Civil engineering essential competency}

The analysis of teaching materials in the curriculum developed by pre-teacher education providers in the field of civil engineering is the initial stage in carrying out development as an effort to obtain essential competencies [3], [4]. The orientation of the development of teaching materials on the achievement of graduates and technological developments as well as meeting the demands of the skills of educators in the 21 st-century era. The minimum technical ability in the field of civil engineering is a prerequisite for prospective pre-graduate education graduates [21], [22]. Referring to the civil engineering body of knowledge for the 21st-century, a person to enter as a civil engineering practitioner at a professional level in the 21 st-century must be able to achieve in the following three groups: foundational outcomes, technical outcomes, and professional outcomes [4], [15]. There are 24 study materials spread across the three groups that are developed into several learning outcomes for the subject. Determination of study materials is based on the needs of graduate users and is the direction of essential technical competencies which include: 1) statics; 2) building construction; 3 ) water structure construction, 4) road and bridge construction, 5) construction design and 6) project management are the minimum essential technical competencies that must be mastered by graduates of pre-teacher education in civil engineering.

The pre-teacher education curriculum is developed not only to meet technical competencies, but also the learning needs of the 21st century and the industrial revolution 4.0. Synergy with the achievements of pre-teacher education graduates for civil engineering vocational schools, vocational professional teachers in the teaching and learning process must take advantage of ICT [23]). The use of ICT in the teaching and learning process by vocational schoolteachers is mostly used to convey the substance of the material to students so that it is easier to understand and access anytime and anywhere [24]-[26]. The results also show that there is a positive relationship between the skills of teachers and learners in the 21st-century era [27].

\subsection{Civil engineering essential competency}

The implementation of digital technology into the construction industry in the 21 st-century era is an unavoidable demand for the world of construction work. Digital construction is based on the use of information and communication technologies for a more efficient and high-quality execution of construction and installation works [11], [21]. Human resources as actors of construction work through vocational education in vocational schools and teachers as transformation agents need to be prepared to be able to meet the demands of digitalization. 
Data analysis revealed that TVE teachers perceived the use of technology in teaching in four qualitatively different ways: (a) increased teacher knowledge, (b) ease of communication, (c) effective teaching, and (d) flexible teaching. Some of the findings are in line with existing phenomenographic studies of teacher conceptions held in the context of university education. This study contributes to the teacher conceptions literature by identifying "flexible teaching" as one of the most significant teaching conceptions in the context of TVE teaching and higher education in general. Research findings can impact teaching practice and faculty development programs at TVE and other higher education institutions [28].

Problem-based learning and project-based learning are commonly used pedagogies that can support the development of practical skills. ICT can, in turn, support and enhance these pedagogical approaches to ensure effective delivery and student engagement [19], [29], [30]. While technology cannot replace the need for direct psychomotor practice in TVET, ICT tools can be used to enhance pedagogy such as project-based learning and problem-based learning, both located in real environments working conditions or simulated through virtual learning packages and interactive content [24], [25], [31].

\subsection{The support of 3D AR-based learning media}

Teaching materials that are realized in the form of 3D AR-based learning media is one of the efforts to realize effective and efficient learning. The characteristics of the learning process include 1) learner-centered; 2) educative interaction between teachers and students; 3) the use of a variety of teaching methods, and 4) supporting learning facilities. Effectiveness is determined by determining the extent to which learning outcomes can be achieved as set out in the curriculum. Meanwhile, efficiency is measured based on the number of components used to achieve the desired results [32]. Accelerating the learning process can be done by providing the widest possible access to teaching materials through m-learning. The benefits of m-learning, as well as e-learning in the world of education, are shown by flexibility of place and time in accessing teaching materials and independent learning which provides the widest opportunity for students to learn without being limited time and limited place [33].

Some of the research results using Augmented Reality 3D as a medium for delivering content in pre-teacher education learning in civil engineering have worked well. Functional usability and compatibility test results show that the application is very feasible to use and works well on several types of Android smartphones with different versions and screen resolutions [11], [13]. In the structural analysis course, the use of $3 \mathrm{D}$ AR allows students to observe the pedestal reaction that occurs and can be interactive by changing the load acting on the support [9], [11].

\section{Conclusion and recommendation}

The conceptual conclusion of the development of learning media content for preteacher civil engineering education based on Augmented reality 3D in the network can be done with the following stages; 1) determine the essential competencies in the field 
of civil engineering by conducting curriculum reviews and validation to graduate users through Delphi techniques; 2) designing learning content as a result of essential competency analysis in one theme; 3) developing learning media based on 3D Augmented reality following the design of learning content in the form of mobile-reality, and 4) product dissemination and evaluation as learning media assets for pre-teacher education study programs in the field of civil engineering.

\section{$5 \quad$ Acknowledgment}

This research was done under the granted of Universitas Negeri Malang.

\section{References}

[1] M. Ed, The Future of Vocational Education and Training in a Changing World. 2012.

[2] S. Billett, Vocational Education. 2011. https://doi.org/10.1007/978-94-007-1954-5

[3] Y. Estriyanto, "A Review of Indonesian Pre-Service Teacher Certification Policy from the Point of View of the Philosophy of Vocational Education," Int. Confrence Teach. Train. Educ., vol. 1, no. 1, pp. 245-253, 2016.

[4] D. Nurhadi and S. Zahro, "Becoming Vocational Teachers for 21st Century in Indonesia," vol. 242, no. Icovet 2018, pp. 143-146, 2019, doi: https://doi.org/10.2991/icovet-18.2019.36

[5] Dirjendikdasmen, Perdirjendikdasmen Nomor 06 Tahun 2018 tentang Spektrum Keahlian SMK/MAK. 2018, pp. 1-10.

[6] H. S. Rosemary Clark, and D.W. Livingstone, Teacher Learning and Power in the Knowledge Society, vol. 53, no. 9. 2013.

[7] K. Jensen, L. C. Lahn, and M. Nerland, Professional Learning in the Knowledge Society. 2012. https://doi.org/10.1007/978-94-6091-994-7

[8] M. Hung and V. President, "Gartner Insights on How to Lead in a Connected World," 2017, [Online]. Available: https://www.gartner.com/imagesrv/books/iot/iotEbook_digital.pdf

[9] T. D. Lynch and C. E. Lynch, Web-Based Education, vol. 8, no. 4. 2002.

[10] Y. S. Chen, B. Lu, and Q. Zeng, Information Science and Technology in Franchising. 2015. https://doi.org/10.4018/978-1-4666-5888-2.ch078

[11] N. Hasanah, M. B. Triyono, G. N. I. P. Pratama, Fadliondi, and I. G. N. D. Paramartha, "Markerless Augmented Reality in Construction Engineering Utilizing Extreme Programming," J. Phys. Conf. Ser., vol. 1737, no. 1, 2021, doi: https://doi.org/10.1088/1742-6596/ $\underline{1737 / 1 / 012021}$

[12] J. Stefaniak, Promoting Learner-Centered Instruction Through the Design of Contextually Relevant Experiences. 2015. https://doi.org/10.1007/978-3-319-16504-2_ 4

[13] P. J. Williams, Technology Education for Teachers. 2012. https://doi.org/10.1007/978-946209-161-0

[14] N. Mulop, K. Mohd Yusof, and Z. Tasir, “The Improvement of Confidence Level of Students Learning Thermodynamics Through a Multimedia Courseware," IEEE Glob. Eng. Educ. Conf. EDUCON, no. April, pp. 733-738, 2014, doi: https://doi.org/10.1109/EDUCON. 2014.6826175

[15] H. A. Alismail and P. McGuire, "21 St Century Standards and Curriculum: Current Research and Practice," J. Educ. Pract., vol. 6, no. 6, pp. 150-155, 2015, [Online]. Available: http:// files.eric.ed.gov/fulltext/EJ1083656.pdf 
[16] Afandi, Sajidan, M. Akhyar, and N. Suryani, "Development Frameworks of the Indonesian Partnership 21st-century Skills Standards for Prospective Science Teachers: A Delphi Study," J. Pendidik. IPA Indones., vol. 8, no. 1, pp. 89-100, 2019, doi: https://doi.org/10.15294/jpii. v8i1.11647

[17] Juharyanto, I. Bafadal, I. Arifin, B. R. Saputra, and M. A. Adha, "The Use of Conventional Communication Technology as an Effective Principal Leadership Strategy in Strengthening the Role of Multi-Stakeholder's Forum for School Quality improvement," Elem. Educ. Online, vol. 19, no. 4, pp. 1963-1973, 2020, doi: https://doi.org/10.17051/ ilkonline.2020.762773

[18] Maisyaroh et al., "The Principals' Efforts in Facilitating the Freedom to Learn by Enhancing Community Participation in Indonesia," Cakrawala Pendidik., vol. 40, no. 1, pp. 196-207, 2021, doi: https://doi.org/10.21831/cp.v40i1.36119

[19] J. Juharyanto, S. Sultoni, I. Arifin, I. Bafadal, A. Nurabadi, and H. Hardika, “'Gethok Tular' as the Leadership Strategy of School Principals to Strengthen Multi-Stakeholder Forum Role in Improving the Quality of One-Roof Schools in Remote Areas in Indonesia," no. 5, 2020, doi: https://doi.org/10.1177/2158244020924374

[20] S. Berney and M. Bétrancourt, "Article Does Animation Enhance Learning? A Meta-analysis Reference Trancourt," Comput. Educ., vol. 101, pp. 150-167, 2016, [Online]. Available: https://doi.org/10.1016/j.compedu.2016.06.005

[21] S. Venkataramani et al., "Scaledeep: A Scalable Compute Architecture for Learning and Evaluating Deep Networks," Proc.-Int. Symp. Comput. Archit., vol. Part F128643, pp. 13-26, 2017, doi: https://doi.org/10.1145/3079856.3080244

[22] K. Subrahmanyam, E. Frison, and M. Michikyan, "The Relation Between Face-To-Face and Digital Interactions and Self-esteem: A Daily Diary Study," Human Behavior and Emerging Technologies, vol. 2, no. 2. pp. 116-127, 2020, doi: https://doi.org/10.1002/hbe2.187

[23] Juharyanto, I. Arifin, N. S. Ariyanti, B. R. Saputra, A. M. A. Sofa, and L. A. Rahmania, "Development of Students' Subject Passion Trends (SSPT) Oriented Constructivistic Learning in Facilitating the Needs of UM Laboratory Elementary School Students," vol. 487, no. Ecpe, pp. 173-178, 2020, doi: https://doi.org/10.2991/assehr.k.201112.031

[24] S. Marshall and W. Taylor, "ICT in Education: Innovation, Implementation, Perceptions and Experiences," Int. J. Educ. Dev. Using Inf. Commun. Technol., vol. 11, no. 1, p. 2, 2015.

[25] R. Huang and J. K. Price, ICT in Education in Global Context. 2014. https://doi. org/10.1007/978-3-662-43927-2

[26] M. M. Isac, P. Dinis Da Costa, L. Araujo, E. S. Calvo, and P. Albergaria-almeida, Teaching Practices in Primary and Secondary Schools in Europe: Insights from Large-Scale Assessments in Education. 2015.

[27] C. Tican and S. Deniz, "Pre-service Teachers' Opinions about the use of 21st century Learner and 21st-century Teacher Skills," Eur. J. Educ. Res., vol. 8, no. 1, pp. 181-197, 2019, doi: https://doi.org/10.12973/eu-jer.8.1.181

[28] M. S. H. Khan, B. O. Abdou, J. Kettunen, and S. Gregory, "A Phenomenographic Research Study of Students' Conceptions of Mobile Learning: An Example from Higher Education," SAGE Open, vol. 9, no. 3, 2019, doi: https://doi.org/10.1177/2158244019861457

[29] I. Arifin, J. Juharyanto, I. Bafadal, and H. Kartini, "Learning Innovation in Strengthening Higher Order Thinking Skill in the Laboratory Elementary School,” 2018, doi: https://doi. org/10.2991/coema-18.2018.39

[30] J. Juharyanto, "The use of Conventional Communication Technology as an Effective Principal Leadership Strategy in Strengthening the Role of Multi-stakeholder's Forum for School Quality Improvement," Ilkögretim Online, pp. 1963-1973, Sep. 2020, doi: https://doi. org/10.17051/ilkonline.2020.762773 
[31] K. Toyama and M. B. Dias, "Information and Communication Technologies for Development," Computer (Long. Beach. Calif)., vol. 41, no. 6, pp. 22-25, 2008, doi: https://doi. org/10.1109/MC.2008.193

[32] S. L. Chang, "The Systematic Design of Instruction," Educ. Technol. Res. Dev., vol. 54, no. 4, pp. 417-420, 2006, doi: https://doi.org/10.1007/s11423-006-9606-0

[33] A. Akhrian Syahidi Politeknik Negeri Banjarmasin et al., "Interactive M-Learning Media Technology to Enhance the Learning Process of Basic Logic Gate Topics in Vocational School and Engineering Education," Int. J. Eng. Educ., vol. 2, no. 2, pp. 50-63, 2020, [Online]. Available: http://dx.doi.org/10.14710/ijee.2.2.50-63

\section{$7 \quad$ Authors}

Machmud Sugandi is a member of IEEE Indonesia Section \#97757136, partner of the journal Pensil, State University of Jakarta, and a lecturer of the Building Engineering Education Study Program/department, Faculty of Engineering, Universitas Negeri Malang (email: r.machmud.ft@um.ac.id).

Juharyanto is a lecturer of Educational Administration/Management, Faculty of Education, Universitas Negeri Malang. He is also journal reviewers of several national and international journal (email: Juharyanto.fip@um.ac.id).

Made Wena is a lecturer of the Building Engineering Education Study Program/ department, Faculty of Engineering, Universitas Negeri Malang (email: made.wena. ft@,um.ac.id).

Sutrisno is a lecturer of the Building Engineering Education Study Program/ department, Faculty of Engineering, Universitas Negeri Malang (email: sutrisno.ft@, um.ac.id).

Article submitted 2021-12-19. Resubmitted 2022-01-20. Final acceptance 2022-01-22. Final version published as submitted by the authors. 